\title{
Ethical Ideologies, Personality Traits, and Whistleblowing Intention in Public Sector: Mediating Role of Whistleblowing Judgment
}

\author{
Intan Salwani Mohamed \\ Universiti Teknologi MARA, Shah Alam, Malaysia \\ Nabilah Rozzani \\ Management \& Science University, Shah Alam, Malaysia \\ Noor Hidayah Ab Aziz \\ Universiti Teknologi MARA, Segamat, Malaysia \\ Richard Hicks \\ Bond University, Queensland, Australia
}

\begin{abstract}
Whistleblowing decision by an individual employee has always been an interesting topic in the management of businesses and organizations. Whistleblowing can be an effective fraud detection mechanism if a person decided to whistleblow on the wrongdoings of other employees. In reality, however, individuals who are aware of unlawful activity of his or her peer group members would face a challenging dilemma if the company or organizations they are working with do not have a sound whistleblowing policy to ensure the confidentiality of whistleblower. Knowing the factors that could influence their whistleblowing judgement and intention would be an interesting topic to be studied. The present study attempts to discuss on factors which would influence whistleblowing intention on staffs from selected public sector organizations in Malaysia. These factors include three individual level factors of ethical ideology (idealism and relativism), personality traits (conscientiousness, openness to experience, extraversion, agreeableness, neuroticism), and whistleblowing judgment, all with regards to peer reporting. A theoretical model is developed in accordance to the issues discussed in this paper.
\end{abstract}

Keywords: whistleblowing intention, whistleblowing judgement, ethical ideology, personality traits

\section{Introduction}

In making decisions on whether to whistleblow or not, the issue of whether the individual factors influence the intention to whistleblow is always asked. Profit and non-profit organisations which are victimised by

\footnotetext{
* Acknowledgment: Authors would like to acknowledge all supports (Grant No. 600-RMI/ARI_IRES 5/3(0042/2016)) provided by Accounting Research Institute (ARI), Universiti Teknologi MARA, Malaysia and Ministry of Higher Education Malaysia. Intan Salwani Mohamed, Ph.D., Dr., Research Fellow, Accounting Research Institute, Universiti Teknologi MARA, Shah Alam, Malaysia.

Nabilah Rozzani, Ph.D., Senior Lecturer, Faculty of Business Management \& Professional Studies, Management \& Science University, Shah Alam, Malaysia.

Noor Hidayah Ab Aziz, Master, Lecturer, Faculty of Accountancy, Universiti Teknologi MARA, Segamat, Malaysia.

Richard Hicks, Ph.D., Professor, Faculty of Society and Design, Bond University, Queensland, Australia.
} 
fraudulent activities and the fact that whistleblowing is a widely held device in identifying fraud motivates a person to decide whether to whistleblow or not. In reality, however, individuals who are aware of unlawful activity of his or her peer group members would face a challenging ethical dilemma. They can simply ignore these wrongdoings and do nothing at all, or otherwise, they could talk to other employees and make a report internally or outside of the organisation. Other than that, they could also confront the offender directly, and try to encourage him or her to undo their inappropriate actions. Or, they may choose another alternative of "peer reporting", which encompasses the revelation of objectionable actions to someone with a perceived authority to stop the activity. Knowing his or her influence to whistleblow is crucial in creating a better workplace and builds robust internal control in a firm, and thus ensuring business prosperity.

However, according to U.S Securities and Exchange Commission's (2014) Report to Congress on Frank-Dodd Whistleblower Program, the number of whistleblowing tips received for the period from 2011 to 2013 has decreased from 150 in 2011 to 12 in 2014. Lavena (2013) agreed that whistleblowing is a rare event within most federal agencies, adding that the existence of covering up fraudulent acts and providing threats to whistleblower are the factors as to why an individual decide not to whistleblow. With fraud cases escalating especially in public sectors, accounting professionals and account department staffs are exposed to ethical dilemmas on regular basis and have the opportunity to uncover wrongdoing regarding their peers, possibly even before the effects are so disastrous that an organisation's viability is in question. For that reason, further understanding of issues and possible positive impacts on whistleblowing should be gathered and tested empirically. Thus, the current research intends to look on how a person's individual factors in making decisions to blow the whistle can provide useful guides for organisations in designing distinct and unprejudiced whistleblowing hotlines to stop organisational illegal behaviour internally.

\section{Literature Review}

\section{Whistleblowers in the Corporate World}

Whistleblowing is a risky opposition form which could bring high risks for the whistleblower (Gokce, 2016). When internal whistleblowing channels failed in an organisation, a whistleblower, who have the intent to disclose the information about a wrongdoing on purpose, would go to third parties outside the firm to make the exposé (Liyanarachchi \& Newdick, 2009). At some point, many of us are likely to observe unlawful activity in our organisations, and some of us may whistleblow to someone with an authority to put a stop to the illegal behaviour (Near \& Miceli, 2016). According to Greenwood (2015), whistleblowing is crucial to the public as a mode of ethical resistance (M. P. Glazer \& P. M. Glazer, 1989), to organisations as a method of communication (Scott, Haseki, \& Kang, 2017), to businesses as a way of notifying management of operational issues (McGlynn III \& Richardson, 2014; Anderson, 2016), to journalists as anonymous sources (Müller \& Drax, 2014), and to public relations, to a certain extent, as a way of dissent by practitioners (Berger \& Reber, 2006). Detert and Burris (2016) found that organisations see improvements in staffs retention and stronger performance when employees are able to voice their concerns freely. They also found that at some financial services organisations with business units whose staffs were reported to have been able to speak up more, would have significantly improved financial and operational results than others. The tales of three well-known whistleblowers who were nominated as Persons of the Year by Time magazine in 2002 (Lacayo \& Ripley, 2002) illustrate these issues, whereby all three were women and two were working in the accounting areas of their organisations: Sherron Watkins of Enron, Coleen Rowley of FBI, and Cynthia Cooper of WorldCom (Near \& 
Miceli, 2016). Generally, whistleblowers are not complainers who would spread bad gossips about the organisation; they are employees who think that they have detected serious illegal behaviour and would like to see it stopped, and in many cases, they assumed that their superiors will appreciate them for acknowledging this crucial piece of information to them (Near \& Miceli, 2016).

The model for predicting behavioural intentions and/or behaviour has been commonly used based on Theory of Reasoned Action (Ajzen \& Fishbein, 1980; Fishbein \& Ajzen, 1975). The model has been effectively applied to forecasting behaviours in numerous areas, such as weight loss, smoking, choice of occupation, and voting choice, and thus this accumulated evidence demonstrates that their theory is suitable in clarifying most social behaviours and applies to most people (Ellis \& Arieli, 1999). Adnan, Nordin, and Rahman (2017) also indicated that the model predicts behavioural intentions and behaviour fairly well, hence the model is suitable for recognising where and how to target approaches for changing behaviours. The theory also suggests that behavioural intentions, which are direct precursors to behaviour, are a function of relevant information or beliefs about the probability that carrying out a particular behaviour will lead to a definite outcome. This study offers guidance in conducting an empirical study on factors that influence a person's whistleblowing intention with regards to ethical ideology, personality traits, and ethical judgment towards peer reporting.

\section{Ethical Ideologies, Whistleblowing Judgment, and Whistleblowing Intention}

Generally, individuals who have been found to judge more harshly on unethical behaviour are likely to score highly on idealism (Forsyth, 1980), be less Machiavellian (Leary, Knight, \& Barnes, 1986), and have greater ethic of caring (Forsyth, Nye, \& Kelley, 1988). According to Trevino and Victor (1992), also Victor, Trevino, and Shapiro (1993), peer reports are more likely to occur when potential whistleblower feels that the interests of his or her group members will be harmed by the peer's actions. According to Barnett, Bass, and Brown (1996), the reason to this is that idealists have strong concern for others' welfare; hence they tend to evaluate potential harm that a peer's wrongdoing might bring to the group. Idealists are also found to interpret wrongdoings as being ethically unacceptable (Mudrack, Bloodgood, \& Turnley, 2012). By that, idealists feel that reporting someone else's unethical actions (being a whistleblower) as being ethically correct (Barnett et al., 1996; Lassar, 2013). Therefore, in terms of disclosing the wrongdoing of a peer, idealists may judge that this is a correct way to protect the interests of the group as a whole. This further suggest that people who are highly sensitive to concerns about the welfare of others will tend to judge peer reporting as an ethical way to protect the interests of the group (Barnett et al., 1996; Trevino \& Victor, 1992).

Meanwhile, according to Forsyth (1980), the ethical ideology of relativism is based on ethical uncertainty, which debates on universal moral standards' applicability, or simply the degree to which universal moral rules are not accepted due to presumably different means of looking at moral dilemmas. Highly relativistic persons are less likely to judge a peer's action harshly, as they claimed that it is difficult to make correct ethical judgment about one's actions without taking into account other specific conditions that might have led to the person's behaviour (Barnett et al., 1996). Barnett et al. (1996) argued that if a relativist is really less likely to form judgments on ethics of the peer's act, it is possible that they are also less likely to think that corrective actions, such as peer reporting are necessary. Prior studies supports this reasoning, for instance, highly relativistic people seem to be more Machiavellian (Leary et al., 1986). Machiavellianism, or Mach, is usually related to individuals with less concern for conventional or conservative morals. High Mach people are deemed to give out different reasoning about ethical dilemmas as compared to others (Christie \& Geis, 2013; Leary et 
al., 1986). In contrary to relativists, Forsyth and Nye (1990) found that non-relativistic individuals would less likely break a social norm for individual benefits. This thus suggests that relativists tend to be more inclined to excuse a wrongdoing that is for personal gains. If this is accurate, relativists are less likely to disclose their knowledge of unethical conduct of a peer to an authorised party (Barnett et al., 1996). Therefore, the proposed hypotheses are as follows:

H1a: Idealism influences an individual's intention to whistleblow;

H1b: Relativism influences an individual's intention not to whistleblow;

H1c: Idealism influences an individual in making whistleblowing judgment;

H1d: Relativism influences an individual in making whistleblowing judgment.

\section{Personality Traits, Whistleblowing Judgment, and Whistleblowing Intention}

Social concern or social responsibility refers to the willingness of an individual or a corporation to behave in a manner which is socially desirable or could benefit others in society (Digman, 1997). Prior research indicates that an individual's sense of social concern or responsibility may be impacted by his or her personality traits (Digman, 1997; Hare, McPherson, \& Forth, 1988; Harland, Staats, \& Wilke, 2007). Digman (1997) examined the relation between social responsibility and the big five personality traits (Norman, 1963; Goldberg, 1992): conscientiousness, openness to experience, extraversion, agreeableness, and neuroticism (emotional stability). Digman (1997) found a positive relation between social responsibility and conscientiousness, openness to experience, extraversion, and agreeableness. Neuroticism is negatively related to social responsibility.

Further, whistleblowing is considered to be a proactive behavior (Miceli \& Near, 1992; Miceli, Near, \& Dworkin, 2008). Personality traits positively associated with proactive behavior are therefore likely to be associated with one's whistleblowing propensity (Bjørkelo, Einarsen, \& Matthiesen, 2010). Therefore, individuals with higher levels of social responsibility are more likely to engage in pro-social behaviours, such as whistleblowing (Dozier \& Micelli, 1985). Therefore, the proposed hypotheses are as follows:

H2a: Conscientiousness influences an individual's intention to whistleblow;

$\mathrm{H} 2 \mathrm{~b}$ : Openness to experience influences an individual's intention not to whistleblow;

H2c: Extraversion influences an individual's intention not to whistleblow;

H2d: Agreeableness influences an individual's intention not to whistleblow;

H2e: Neuroticism influences an individual's intention not to whistleblow;

H2f: Conscientiousness influences an individual in making whistleblowing judgment;

$\mathrm{H} 2 \mathrm{~g}$ : Openness to experience influences an individual in making whistleblowing judgment;

$\mathrm{H} 2 \mathrm{~h}$ :Extraversion influences an individual in making whistleblowing judgment;

H2i: Agreeableness influences an individual in making whistleblowing judgment;

$\mathrm{H} 2 \mathrm{j}$ : Neuroticism influences an individual in making whistleblowing judgment.

\section{Whistleblowing Judgment and Whistleblowing Intention}

Ethical judgment or morality (Mesmer-Magnus \& Viswesvaran, 2005) denotes an individual's belief that a certain behaviour is the most ethical alternative or the perfect ethical decision when behavioural intention is referred to the process of deciding a certain act from a set of alternatives (Hunt \& Vitell, 1986). Because it is an essential element of a person's behaviour toward ethical dilemmas, it is also a factor in shaping behavioural intention towards a questionable situation (Chiu, 2003; Jones, 1991). In actual fact, ethical judgment is contained 
within many frameworks of ethical decision-making, such as Hunt and Vitell (1986), Jones (1991), and also Rest (1986). Both contextual (situational) and individual factors have been discovered in the literature as probable influences on a person's choices to whistleblow. Other important personal factors also consist of gender (Sims \& Keenan, 1999); religious and ideal values (Miceli \& Near, 1992; Sims \& Keenan, 1999); moral standards and judgment (Miceli, Near, \& Schwenk, 1991); also individual locus of control (Miceli \& Near, 1992).

Experimental studies had evidences that respondents who judge an action to be highly ethical and assume other peoples' acceptance of this action tend to have behavioural intention to carry out that behaviour (Ajzen, 2002). In actual fact, most ethical decision-making frameworks posit that intention alters the relationship between ethical judgments and ethical behaviour. Taylor and Curtis (2010) pointed out that individuals whistleblow because of their own morality (i.e., ethical judgment)-they feel a responsibility to report. In addition, the AICPA Code of Professional Conduct (AICPA, 2006) creates responsibility by requiring auditors to report certain violations. Therefore, intention and judgment are vital in making psychological choices during decision-making process for a future whistleblower. Currently, studies on personal variables of whistleblowing intention have become a subject of interest amongst researchers (Ghani, Galbreath, \& Evans, 2011; Taylor \& Curtis, 2010; Zhang, Chiu, \& Wei, 2009). However, studies on relationships between certain personal variables and whistleblowing intention are still debateable (Miceli et al., 2008). Most ethical decision-making frameworks contain ethical judgment as a variable that influences the construction of behavioural intentions with regards to a questionable act (Barnett et al., 1996; Jones, 1991; Hunt \& Vitell, 1986; Rest, 1986). Prior studies thus proposed that, at par with Theory of Reasoned Action by Ajzen and Fishbein (1980), people who judge an act to be highly ethical tends to develop behavioural intentions to execute the act. Therefore, it is likely that whistleblowing judgment influences whistleblowing intentions to report a peer. The third hypothesis comprises of two vital elements in ethical decision-making models, namely ethical judgment and behavioural intention (Zhang et al., 2009).

H3: Whistleblowing Judgment influences Whistleblowing Intention.

\section{Conclusions}

Most peer reporting research has emphasised largely on contextual factors that are deemed to influence peer reporting decisions, such as role responsibility, group interests, and justice evaluations (Trevino \& Victor, 1992; Victor et al., 1993; Loyens, 2013). However, studies on individual characteristics are still lacking (Barnett et al., 1996). The present study aims to propose relationships between individual characteristics based on their cognitive aspects or their subjective norms, namely their personality traits (dimensions of conscientiousness, openness to experience, extraversion, agreeableness, and neuroticism) and their beliefs from ethical ideology aspects (dimensions of idealism and relativism). The proposed theoretical framework is thus developed from Theory of Reasoned Action, where Fig. 1 is the schematic presentation of the model examining relationships between each antecedent variable in the model. The developed model derives whistleblowing behavioural intention based on prior literatures that will be discussed in the next sections. This study posits that: (1) account department staffs in selected Malaysian public sector institutions adherence to certain moral philosophies (ethical ideology) and personality traits may influence their whistleblowing judgment; and (2) account department staffs in selected public sector institutions in Malaysia adherence to idealism, relativism, conscientiousness, openness to experience, extraversion, agreeableness, neuroticism, and their whistleblowing judgment may influence their intention to whistleblow. 


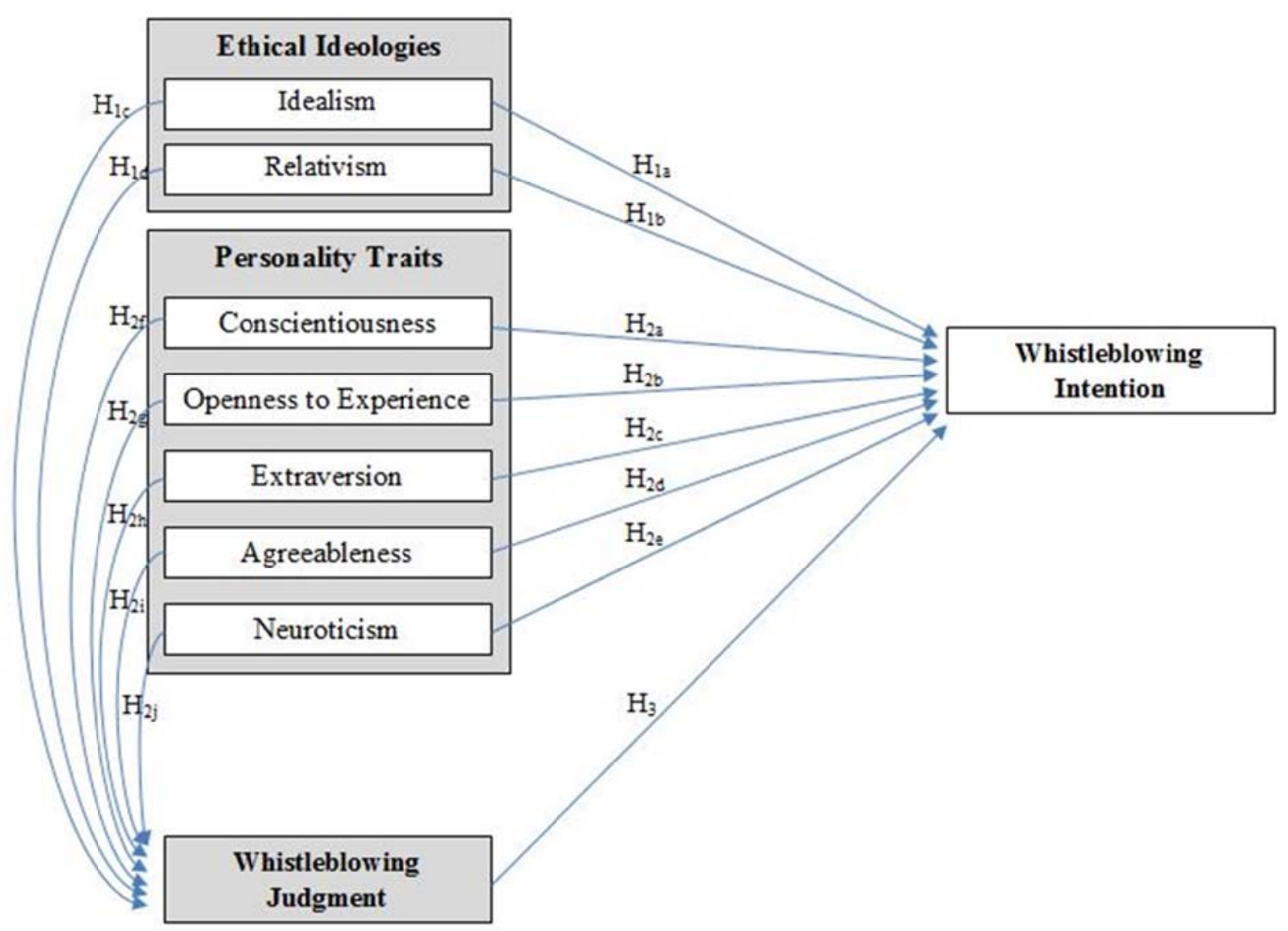

Figure 1. Proposed theoretical framework (Source: Ajzen \& Fishbein, 1980; Barnett et al., 19196; Digman, 1997).

\section{References}

Adnan, N., Nordin, S. M., \& Rahman, I. (2017). Adoption of PHEV/EV in Malaysia: A critical review on predicting consumer behaviour. Renewable and Sustainable Energy Reviews, 72, 849-862.

Ajzen, I. (2002). Perceived behavioral control, self-efficacy, locus of control, and the theory of planned behavior. Journal of Applied Social Psychology, 32, 665-683.

Ajzen, I., \& Fishbein, M. (1980). Understanding attitudes and predicting social behaviour. Englewood Cliffs, New Jersey: Prentice-Hall, Inc.

American Institute of Certified Public Accountants (AICPA). (2006). AICPA code of professional conduct: Employment or association with attest clients (Interpretation 101-2). Retrieved May 2, 2016, from http://www.aicpa.org/about/code/index.html

Anderson, G. (2016). How well are you managing your company's reputation risk? Governance Directions, 68(5), $290-293$.

Barnett, T., Bass, K., \& Brown, G. (1996). Religiosity, ethical ideology, and intentions to report a peer's wrongdoing. Journal of Business Ethics, 15(11), 1161-1174.

Berger, B. K., \& Reber, B. H. (2006). Gaining influence in public relations: The role of resistance in practice. Mahwah. NJ: Lawrence Erlbaum Associates.

Bjørkelo, B., Einarsen, S., \& Matthiesen, S. B. (2010). Predicting proactive behaviour at work: Exploring the role of personality as an antecedent of whistleblowing behavior. Journal of Occupational and Organizational Psychology, 83, 371-394.

Chiu, R. K. (2003). Ethical judgment and whistleblowing intention: Examining the moderating role of locus of control. Journal of Business Ethics, 43(1-2), 65-74.

Christie, R., \& Geis, F. L. (2013). Studies in machiavellianism. New York, NY: Academic Press.

Detert, J. R., \& Burris, E. R. (2016). Can your employees really speak freely? Harvard Business Review, 94(1-2), 80-87. 
Digman, J. M. (1997). Higher-order factors of the big five. Journal of Personality and Social Psychology, 73(6), 1246-1256.

Dozier, J. B., \& Micelli, M. P. (1985). Potential predictors of whistleblowing: A prosocial behavior perspective. The Academy of Management Review, 10(4), 823-836.

Ellis, S., \& Arieli, S. (1999). Predicting intentions to report administrative and disciplinary infractions: Applying the reasoned action model. Human Relations, ABI/INFORM Global, 52(7), 947.

Field, A. (2009). Discovering statistics using SPSS (3rd ed.). London: Sage Publications Ltd.

Fishbein, M., \& Ajzen, I. (1975). Belief, attitudes, intention, and behaviour: An introduction to theory and research. Massachussets: Addison-Wesley.

Forsyth, D. R. (1980). A taxonomy of ethical ideologies. Journal of Personality and Social psychology, 39(1), 175.

Forsyth, D. R., \& Nye, J. L. (1990). Personal moral philosophies and moral choice. Journal of Research in Personality, 24(4), 398-414.

Forsyth, D. R., Nye, J. L., \& Kelley, K. (1988). Idealism, relativism, and the ethic of caring. The Journal of Psychology, 122(3), 243-248.

Ghani, N. A., Galbreath, J., \& Evans, R. (2011). Predicting whistle-blowing intention among supervisors in Malaysia. In Othman, M.D. (Ed.), Annual Summit on Business and Entrepreneurial Studies (ASBES 2011) Proceeding (pp. 48-67). Malaysia: Global Research Agency.

Glazer, M. P., \& Glazer, P. M. (1989). The whistleblowers: Exposing corruption in government and industry. New York, NY: Basic Books.

Gokce, A. T. (2016). The effect of teachers' spirituality and ethical ideology on their preference of reporting wrongdoings at schools. International Education Studies, 9(5), 85.

Goldberg, L. (1992). The development of markers for the big-five factor structure. Psychological Assessment, 4(1), $26-42$.

Greenwood, C. A. (2015). Whistleblowing in the Fortune 1000: What practitioners told us about wrongdoing in corporations in a pilot study. Public Relations Review, 41(4), 490-500.

Hare, R. D., McPherson, L. M., \& Forth, A. E. (1988). Male psychopaths and their criminal careers. Journal of Consulting and Clinical Psychology, 56(5), 710-714.

Harland, P., Staats, H., \& Wilke, H. A. M. (2007). Situational and personality factors as direct or personal norm mediated predictors of pro-environmental behavior: Questions derived from norm-activation theory. Basic and Applied Social Psychology, 29(4), 323-334.

Hunt, S. D., \& Vitell, S. (1986). A general theory of marketing ethics. Journal of macromarketing, 6(1), 5-16.

Jones, T. M. (1991). Ethical decision-making by individuals in organizations: An issue contingent model. Academy of Management Review, 16(2), 366-395.

Lacayo, R., \& Ripley, A. (2002, December 30). Persons of the Year 2002: Cynthia Cooper, Coleen Rowley, and Sherron Watkins. Persons of the Year by Time, 160(27), 30-33.

Lassar, W. M. (2013). An empirical evaluation of Graham's model of principled organizational dissent in the whistleblower context post-SOX Blaise M. Sonnier. Journal of Forensic \& Investigative Accounting, 5(2).

Lavena, C. F. (2013). Deciding to blow the whistle: How individual and organizational factors influence the reporting of wrongdoing in the federal government (Doctoral dissertation, Graduate School, Newark, Rutgers University).

Leary, M. R., Knight, P. D., \& Barnes, B. D. (1986). Ethical ideologies of the Machiavellian. Personality and Social Psychology Bulletin, 12(1), 75-80.

Liyanarachchi, G., \& Newdick, C. (2009). The impact of moral reasoning and retaliation on whistle-blowing: New Zealand evidence. Journal of Business Ethics, 89(1), 37-57.

Loyens, K. (2013). Towards a custom-made whistleblowing policy: Using grid-group cultural theory to match policy measures to different styles of peer reporting. Journal of Business Ethics, 114(2), 239-249.

Madden, T. J., Ellen, P. S., \& Ajzen, I. (1992). A comparison of the theory of planned behaviour and the theory of reasoned action. Personality and social psychology Bulletin, 18(1), 3-9.

Mat Rais, M. T., Mohammad, Azman, M. R. S., Krishnasamy, K. S., \& Haron, H. (2017). Corporate Governance in Air Asia Berhad. The FGIC 1st Conference on Governance \& Integrity, 3-4 April, Kuantan, Malaysia.

McCabe, D. L., \& Trevino, L. K. (1997). Individual and contextual influences on academic dishonesty: A multicampus investigation. Research in Higher Education, 38(3), 379-396.

McGlynn III, J., \& Richardson, B. K. (2014). Private support, public alienation: Whistle blowers and the paradox of social support. Western Journal of Communication, 78(2), 213-237. 
Mesmer-Magnus, J. R., \& Viswesvaran, C. (2005). Whistleblowing in organizations: An examination of correlates of whistleblowing intentions, actions, and retaliation. Journal of Business Ethics, 62(3), 277-297.

Miceli, M. P., \& Near, J. P. (1992). Blowing the whistle: The organizational and legal implications for companies and employees. New York, NY: Lexington Books.

Miceli, M., Near, J., \& Dworkin, T. (2008). Whistleblowing in organizations. New York, NY: Routledge, Taylor and Francis Group.

Miceli, M. P., Near, J. P., \& Schwenk, C. R. (1991). Who blows the whistle and why? Industrial \& Labor Relations Review, 45(1), 113-130.

Mudrack, P. E., Bloodgood, J. M., \& Turnley, W. H. (2012). Some ethical implications of individual competitiveness. Journal of Business Ethics, 108(3), 347-359.

Müller, R., \& Drax, C. (2014). Organizational challenges and phases of implementation and optimization. In Aviation Risk and Safety Management (pp. 153-213). New York, NY: Springer International Publishing.

Mustapha, M., \& Siaw, L. S. (2012). Will final year accountancy students whistle blow? A Malaysian case. International Journal of Trade, Economics and Finance, 3(5), 327.

Near, J. P., \& Miceli, M. P. (2016). After the wrongdoing: What managers should know about whistleblowing. Business Horizons, 59(1), 105-114.

Norman, W. T. (1963). Toward an adequate taxonomy of personality attributes: Replicated factor structure in peer nomination personality ratings. Journal of Abnormal Social Psychology, 66(1), 574-583.

Rest, J. R. (1986). Moral development: Advances in research and theory. New York, NY: Praeger Publishers.

Scott, C. R., Haseki, M., \& Kang, K. (2017). Anonymous organizational communication. Annals of the International Communication Association, 35(1), 299-340.

Sims, R. L., \& Keenan, J. P. (1999). A cross-cultural comparison of managers' whistleblowing tendencies. International Journal of Value-Based Management, 12(2), 137-151.

Taylor, E. Z., \& Curtis, M. B. (2010). An examination of the layers of workplace influences in ethical judgments: Whistleblowing likelihood and perseverance in public accounting. Journal of Business Ethics, 93(1), 21-37.

Trevino, L. K., \& Victor, B. (1992). Peer reporting of unethical behavior: A social context perspective. Academy of Management Journal, 35(1), 38-64.

U.S. Securities \& Exchange Commission. (2014). 2014 Report to Congress on the Frank-Dodd Whistleblower Program. Retrieved from http://www.sec.gov/about/offices/owb/annual-report-2014.pdf

Victor, B., Trevino, L. K., \& Shapiro, D. L. (1993). Peer reporting of unethical behavior: The influence of justice evaluations and social context factors. Journal of Business Ethics, 12(4), 253-263.

Zhang, J., Chiu, R., \& Wei, L. Q. (2009). On whistleblowing judgment and intention: The roles of positive mood and organizational ethical culture. Journal of Managerial Psychology, 24(7), 627-649. 